\title{
The Relationship between Government Revenue and Expenditure in Qatar: A Cointegration and Causality Investigation
}

\author{
Abdulla S. Al-Khulaifi \\ Correspondence: P.O.Box 1112 Doha, Qatar. Tel: 97-45-556-3724. E-mail: a.alkhulaifi@qu.edu.qa \\ Received: June 28, 2012 \\ Accepted: July 15, 2012 \\ Online Published: July 31, 2012 \\ doi:10.5539/ijef.v4n9p142 \\ URL: http://dx.doi.org/10.5539/ijef.v4n9p142
}

\begin{abstract}
The main purpose of this paper is to examine the relationship between government revenue and expenditure in Qatar. Annual data for the period from 1980-2011 were used and a time series analysis of unit root tests, Engle-Granger's cointegration and Granger causality were applied. The paper found that variables were integrated of order one when Augmented Dickey-Fuller and Phillip-Perron unit root tests were employed. The variables were found to be cointegrated. Empirical results found unidirectional causality that runs from government revenue to expenditure in support of revenue-spend hypothesis.
\end{abstract}

Keywords: cointegration, granger causality, government revenue, government expenditure, Qatar

JEL: C22, H2, H5, H62

\section{Introduction}

The relationship between government revenue and expenditure is a major concern for economists and policy makers alike. This controversial issue has been the subject of extensive theoretical and empirical research for decades. This research became more important and relevant since governments have been incurring continuous budget deficit in both developed and developing countries. Understanding this relationship is an important element for an effective fiscal policy. The study of the causal link between government revenue and expenditure has resulted in four hypotheses that have been under empirical scrutiny in the literature. The first hypothesis is the tax (revenue)-spend hypothesis. It suggests that changes in revenues induce change in expenditures, but not the reverse. In this case government revenue is said to Granger cause government expenditure. The second is the spend-tax (revenue) hypothesis. This hypothesis takes the opposite view of the first one. Changes in government expenditure are said to Granger cause government revenue without a feedback. The third hypothesis is the fiscal synchronization. This hypothesis proposes that revenue and expenditure decisions are made jointly. This implies bidirectional causality between the two variables. The fourth hypothesis is the institutional separation of government revenue and expenditure decisions of government. In this case there is no causality between the two variables, and hence they are independent of one another.

Fiscal policy occupies an important status among economic policies in Qatar. The use of fiscal policy, in addition to achieving its macroeconomic goals of economic growth, employment and price stability, is used to achieve economic and social development. Therefore, Qatar state budget is used to promote and achieve the government economic goals, through directing government expenditure towards building infrastructure, education, healthcare and housing to raise standard of living. Government expenditure acts as a major component of GDP in Qatar averaging about 30\% in the last decade. During the period of study, government expenditure increased from 11 billion Qatari Riyals (QR) in 1980/81 to a record QR 174.5 Billion in fiscal year 2011/2012. The successive annual budgets have shown increasing expenditure on economic services, social welfare, housing and infrastructure construction all for the goal of improving quality of life of citizens. Current expenditure increased over the period to accommodate the increase in wages and salaries which constitute a large portion of state budget. Government revenue on the other hand, is procyclical due to its reliance on oil revenue and hence oil prices. Oil prices are determined in the global market by supply and demand. Therefore, government revenue has experienced a sharp decline when oil prices decreased. This was the case in the mid-1980s. This forced the government to decrease its expenditure, and experience budget deficit for the years 1986-1991 and from 1993-1999. Deficits were financed from previous years surplus and from reserves. Recent years revenues have experienced an increase in oil and gas revenues. Another inflow to the budget comes from investment revenue. This item has been increasing in the last decade since the government uses surplus in the 
state budget in global investments, which led to an increase in government revenue. Table (1) shows government revenue, expenditure and surplus (deficit) for Qatar for selected years of the period under investigation.

Table 1. Government Revenues and Expenditures for Selected Years (Mill Q.R.)

\begin{tabular}{llll}
\hline Year & Gov. Revenue & Gov. Expenditure & Surplus (Deficit) \\
\hline 1980 & 19004 & 10937 & 8067 \\
1985 & 13393 & 11574 & 1819 \\
1990 & 10182 & 10375 & $(183)$ \\
1995 & 9680 & 11786 & $(2106)$ \\
2000 & 23291 & 18895 & 4396 \\
2005 & 65685 & 50768 & 14917 \\
2010 & 155906 & 142424 & 13482 \\
\hline
\end{tabular}

Qatar Central Bank, Annual Reports. Author's Calculation.

It is therefore important to empirically study the causal relationship between government revenue and expenditure in Qatar's economy. The main purpose of this paper is to investigate the relationship between government revenue and expenditure in Qatar for the period from 1980-2011. The paper is divided into five sections. Following this introduction, literature review of relevant studies will be presented. Section three will discuss data and methodology that is used in this research. Empirical results are reported in section four. Section five will conclude this exercise.

\section{Literature Review}

The literature on researching the relationship between government revenue and expenditure are extensive for many countries in both developed and developing economies. Tsen and Kian-Ping (2005) examined this relationship in Malaysia for the period from 1965 - 2002. Augmented Dickey-Fuller and Phillips-Perron Unit root tests, Johansen cointegration and error correction models were applied to data. The results supported tax-spend hypothesis. Government revenue was found to Granger cause expenditure in Malaysia.

Nyamongo et al. (2007) in a study of the government revenue and expenditure nexus in South Africa found different results. A monthly data was used, and modified unit root test and Vector Error Correction Model (VECM) were applied on data. It was found that government revenue and expenditure are cointegrated, and a long-run relationship exists between them. Applying Granger causality through VECM model, it was found bidirectional Granger causality which supports fiscal synchronization hypothesis. In the short-run no Granger causality was found between variable, suggesting fiscal neutrality hypothesis in South Africa for the period of study.

Amoah and Loloh (2008) studied the causal linkages between government revenue and spending in Ghana. Researchers used annual data for the period from 1983-2077 which was converted into quarterly data. Real and nominal values of variables were used in models. Time series variables were found to be integrated of order one for both nominal and real values. Engle-Granger bivariate methodology was applied to test for existence of cointegration. It was found that the revenue and expenditure are cointegrated. An error correction model was specified, long-run and short-run causality were obtained. Causality was found to run from expenditure to revenue in the long-run supporting spend-tax hypothesis, while revenue Granger cause expenditure in the short-run in support of tax-spend hypothesis.

Eita and Mbazima (2008) found unidirectional causality between government revenue and expenditure in the case of Namibia. Granger causality through vector autoregression (VAR) method and annual data for the period from 1977 - 2007 were used. The paper provided evidence to support tax-spend hypothesis in Namibia.

In Pakistan, The verdict is still out for the causality direction between government revenue and expenditure. Aisha and Khatoon (2009) in a study of Pakistan economy for the period from 1972-2007, used a time series methodology of unit root test, Engle-Granger approach of cointegration and error correction model were applied to data. Government revenue and expenditure were found to be cointegrated. Where Granger causality test was performed, it was found that government expenditure Granger cause revenue verifying spend-tax hypothesis. Subhani et al. (2012) found the opposite causality direction confirming the tax-spend hypothesis. They studied 
the causality direction between government expenditure and revenue for Pakistan. Annual data for the period from 1979-2010 were used, and Granger causality was applied to variables in question. The paper found that government revenue Granger cause government expenditure in Pakistan for the period under investigation.

Sadiq (2010) on the other hand, found no causality between the two variables in Pakistan. Granger causality was used to study the relationship between federal and provincial taxes and expenditure in Pakistan for the period from 1980-81 to 2009-10. No Granger causality was found between revenue and expenditure in the federal and provincial level for the period of study.

Ravinthirakumaran (2011) examined the relationship between government revenue and expenditure in Sri Lanka for the period from 1977-2009. A time series methodology of Engle-Granger's approach of cointegration and error correction model framework is investigated. The study concluded that bidirectional causality exists between government revenue and expenditure and there is long-run equilibrium between the two variables in Sri Lanka economy.

Elyasi and Rahimi (2012) found bidirectional causality between government revenue and expenditure in Iran. Annual data for the period from 1963-2007 were used, and variables were tested for stationarity. The paper included a comprehensive list of studies on causality between government revenue and expenditure for country specific and for multi-countries studies. The evidence cited on the direction of causality is mixed in those studies. Different data sets, econometric methodologies and different country characteristics are some of reasons cited for the different results on the direction of causality.

The evidence on the relationship between government revenue and expenditure for Middle Eastern countries is scarce. It is more so for the Gulf countries and especially for Qatar. These studies are important to our paper since most of the countries are developing countries, oil producing and oil dependent in their sources of revenue. Petanla and Sadeghi (2012) investigated the relationship between government revenue and expenditure in fifteen oil-exporting countries. Panel VAR framework was applied on annual data for the period from 2000-2009. Oil revenue was used as a proxy for government revenue, since it accounts for most of total government revenue. The study found that there is a unidirectional long-run causality that runs from oil revenue to government expenditure.

Fasano and Wang (2002) is a leading study that has tested the relationship between government spending and revenue for the GCC countries. Those countries include Bahrain, Kuwait, Oman, Qatar, Saudi Arabia and The United Arab Emirates. To the best of the author's knowledge, this is the only study that included Qatar in this subject. Annual data for the period 1975-2000 were used for all countries under investigation. The empirical results supported revenue-spend hypothesis for Bahrain, United Arab Emirates and Oman. Government revenue was found to Granger cause expenditure in these three countries. The evidence of bidirectional causality was found for Kuwait, Qatar and Saudi Arabia.

Al-Qudair (2005) studied the relationship between government expenditure and revenue in Saudi Arabia. A country that depends heavily on its oil exports as the main source of government revenue. A time series analysis of unit root, Engle-Granger cointegration technique and an error correction model were used. The study found bidirectional causality exists between government revenue and expenditure in support of fiscal synchronization hypothesis. The result confirms earlier findings by Fasano and Wang (2002) on Saudi Arabia.

Batainah (undated) in a study of Jordanian economy applied Johansen cointegration approach and error correction model. The result supported the spend-revenue hypothesis. Government expenditure was found to Granger cause revenue for the period from 1980-2008.

\section{Data and Methodology}

Data on government revenue and government expenditure were obtained from Qatar Central Bank annual reports. The variables were in nominal values. GDP deflator was used to convert nominal into real values of variables. This variable was available from Qatar Statistical Authority web site. Annual data for the period from 1980 2011 are used in this study.

Since most time series variables are non-stationary, unit root tests are useful to determine the order of integration of the variables. The first step in the empirical estimation is to test perform unit root test as to see the univariate characteristics of variables, which show whether the variables are stationary or non-stationary. If variable is stationary, it is said to be integrated of order zero or $I(0)$. If a variable is not stationary in its level form but stationary in its first differenced form, it is said to be integrated of order one or $I(1)$. One of the most popular tests of unit root is the Augmented Dickey Fuller (ADF) test. The testing procedure for the ADF is applied on the following model: 


$$
\Delta X_{t}=a_{0}+a_{1} t+a_{2} X_{t-1}+\sum_{i=1}^{\rho} c_{i} \Delta X_{t-i}+\varepsilon_{i t}
$$

Where $X_{t}$ is the series being tested, $\mathrm{t}$ is a linear time trend, $\rho$ is the number of lagged differences included to capture any autocorrelation, and $\Delta$ is the first difference operator. The null hypothesis for unit root is $\mathrm{H} 0: \mathrm{a}_{2}=0$. This test will be applied to each of the variables to determine the stationarity property in their levels and in their first-difference. Another unit root test is the Phillip-Perron (1988) test. This test proposes an alternative nonparametric method to take care of serial correlation in error terms without adding lagged difference terms when testing for a unit root (Gujarati and Porter 2009). This study will apply both tests of unit root.

In economics two variables are cointegrated if they have a long-run or equilibrium relationship between them. In the case of two variables $X_{t}$ and $Y_{t}$, that are integrated of order d, I (d). If there exists a linear combination such that the disturbance term $\varepsilon_{\mathrm{t}}$ from regression is of a lower order of integration, $\mathrm{I}(\mathrm{d}-\mathrm{b})$, and $\mathrm{b}>0$, then Engle and Granger (1987) define $X_{t}$ and $Y_{t}$ as cointegrated. Thus, if $X_{t}$ and $Y_{t}$ were both I(1), and residuals $\varepsilon_{t}$ are $I(0)$, the two series would be cointegrated (Harris 1995:52). The Engle and Granger (1987) two step procedures for modeling the relationship between cointegrated variables is as follow: First, The order of integration of the variables $X_{t}$ and $Y_{t}$ is determined by employing the unit root test. We run the OLS regression on what is called the cointegrating regression:

$$
X_{t}=a_{0}+a_{1} Y_{t}+\varepsilon_{t}
$$

Second, we test whether the residuals $\varepsilon_{\mathrm{t}}$, from the regression are stationary. If $X_{t}$ and $Y_{t}$ not cointegrated, any linear combination of them will be non-stationary, and hence the residuals will be non-stationary (pindyck and Rubinfeld 1998).

The concept of causality is due to Granger (1969), and according to him a variable $\mathrm{X}$ is caused by $\mathrm{Y}$ if $\mathrm{X}$ is better predicted from past values of $\mathrm{Y}$ and $\mathrm{X}$ together rather than from past values of $\mathrm{X}$ alone. Four patterns of causality can be distinguished: a) unidirectional causality from $X$ to $Y$, denoted $X \rightarrow Y, b$ ) unidirectional causality from $\mathrm{Y}$ to $\mathrm{X}$, denoted $\mathrm{Y} \rightarrow \mathrm{X}, \mathrm{c}$ ) feedback or bidirectional causality, and d) no causality. The simplest Granger causality test is:

$$
\begin{gathered}
X_{t}=a_{0}+\sum a_{1 i} X_{t-i}+\sum a_{2 i} Y_{t-i}+\varepsilon_{t} \\
Y_{t}=b_{0}+\sum b_{1 i} Y_{t-i}+\sum b_{2 i} X_{t-i}+\mu_{t}
\end{gathered}
$$

The Granger causality can be tested through the null hypothesis in equation (3) is that $\mathrm{Y}$ does not cause $\mathrm{X}$, that is $\mathrm{a} 2 \mathrm{i}=\mathrm{o}$ for all $\mathrm{i}$, and for equation (4) the null hypothesis is $\mathrm{X}$ does not cause $\mathrm{Y}$, or $\mathrm{b} 2 \mathrm{i}=0$ for all $\mathrm{i}$. If $\mathrm{a} 2 \mathrm{i}=0$ and $\mathrm{b} 2 \mathrm{i}=0$ for all $\mathrm{i}$, we conclude that there is no causality between $\mathrm{X}$ and $\mathrm{Y}$. If both of the null hypotheses are rejected, that is $\mathrm{a} 2 \mathrm{i} \neq 0$ and $\mathrm{b} 2 \mathrm{i} \neq 0$, then there is bidirectional relationship exist between the two variables $\mathrm{X}$ and Y. This simple Granger causality is valid only for a stationary series $I(0)$. If time-series included in the analysis are $I(1)$ and cointegrated, the simple Granger causality test should not be used. In this case, Engle and Granger (1987) provide a more comprehensive procedure known as error-correction model (ECM) for causality test. In the ECM model we incorporate information from the cointegrating regression in the form of residuals term lagged once, and include the variables after made stationary by differencing them. The ECM is formulated to test causality as follow:

$$
\begin{aligned}
\Delta X_{t} & =a_{0}+\sum a_{1 i} \Delta X_{t-i}+\sum a_{2 i} \Delta Y_{t-j}-a_{3} E C T_{t-1}+o_{t} \\
\Delta Y_{t} & =b_{0}+\sum b_{1 i} \Delta X_{t-j}+\sum b_{2 i} \Delta Y_{t-j}-b_{3} E C T_{t-1}+\tau_{t}
\end{aligned}
$$

Where $E C T_{t-1}$ is the error-correction term lagged one period. The $\Delta X$ and $\Delta Y$ are differenced time-series of $\mathrm{X}$ and $\mathrm{Y}$ respectively. $\mathrm{O}_{\mathrm{t}}$ and $\tau_{\mathrm{t}}$ are white noise error terms. The independent variable is said to cause the dependent variable if the error term $\left(E C T_{t-1}\right)$ is significant, or the coefficients of the lagged independent variable are jointly significant. Negative and statistically significant values of the coefficients of the error correction terms indicate the existence of long run causality. Causality test should be based on equations (5) and (6) when series are found to be cointegrated. 


\section{Empirical Results}

The univariate characteristics of the variables government revenue and government expenditure are tested. Both Augmented Dickey-Fuller (ADF) and Phillip-Perron (PP) unit root tests were applied, and results are shown in tables (2) and (3). The ADF and PP tests show that both variables are non-stationary in level. Only when the variables were differenced once, they became stationary. Therefore, government revenue (LRGREV) and government expenditure (LRGEXP) are integrated of order one $I(1)$.

Table 2. Augmented Dickey-Fuller Unit Root Test

\begin{tabular}{llll}
\hline Variable & Constant & Constant \& Trend & None \\
\hline LRGREV & $0.9532(1)$ & $-1.6919(1)$ & $1.7076(1)$ \\
$\Delta$ LRGREV & $-7.5368^{* * *}(0)$ & $-8.6187^{* * *}(0)$ & $-3.3387^{* * *}(1)$ \\
LRGEXP & $-0.0952(0)$ & $-1.6713(0)$ & $1.8140(0)$ \\
$\Delta$ LRGEXP & $-5.9955^{* * *}(0)$ & $-4.0765^{* *}(3)$ & $-5.5617^{* * *}(0)$
\end{tabular}

LRGREV is log of real government revenue, LRGEXP is log of real government expenditure, $\Delta$ is first difference operator. $* *, * * *$ Significant at $5 \%$ and $1 \%$ respectively. Numbers between parenthesis are lag length using Schwarz Info criterion automatic maximum lag=7.

Table 3. Phillips-Perron Unit Root Test

\begin{tabular}{llll}
\hline Variable & Constant & Constant \&Trend & None \\
\hline LRGREV & $0.1767(0)$ & $-1.8278(4)$ & $1.4888(1)$ \\
$\Delta$ LRGREV & $-7.3769^{* * *}(2)$ & $-12.261 * * *(9)$ & $-6.931 * * *(3)$ \\
LRGEXP & $0.5531(14)$ & $-1.4667(4)$ & $3.2198(23)$ \\
$\Delta$ LRGEXP & $-6.2443 * * *(12)$ & $-10.759 * * *(20)$ & $-5.605 * * *(3)$
\end{tabular}

LRGREV is log of real government revenue, LRGEXP is log of real government expenditure, $\Delta$ is first difference operator. $* * *$ Significant at $1 \%$. Numbers between parenthesis are Band width (Newey-West Automatic) using Bartlett Karnel.

Engle-Granger's cointegration method is then applied to both variables since they are integrated of the same order. The results of ADF of residuals are shown in table (4).

Table 4. Engle-Granger Cointegration Test and Long-run Relationship

\begin{tabular}{lll}
\hline Cointegration Regression & Adj. $\mathrm{R}^{2}$ & ADF \\
\hline LRGREV $=-1.926+1.189$ LRGEXP & 0.83 & $-3.932^{* *}$ \\
\hline LRGEXP $=3.044+0.701$ LRGREV & 0.83 & $-4.219^{* *}$
\end{tabular}

LRGREV is log of real government revenue; LRGEXP is log of real government expenditure.

** Significant at 5\% MacKinnon (1996) p-values.

Equation (2) was estimated with government expenditure as the dependent variable, and government revenue as the independent variable. The residuals are tested for stationarity via ADF unit root test. The ADF value was -4.66 , which is less than MacKinnon critical value at 5\% significance level. Also equation (2) was estimated with government revenue as the dependent variable, and government expenditure as the independent variable. The residuals were tested for stationarity. The ADF value was -3.93 , which is also less than MacKinnon critical value at $5 \%$ significance level. We conclude that residuals are stationary and variables are cointegrated, and a long-run relationship between government revenue and expenditure exist.

Since there is cointegration between the variables, we move to test the direction of causality using error correction model. Table (5) shows Granger causality results. The results show that there is unidirectional causality runs from government revenue to government expenditure. This result support revenue-spend 
hypothesis. Although not shown here, the coefficient of the lagged error correction term for the government expenditure model is negative and significant, which implies that there is a long-run causal relationship from government revenue to government expenditure in Qatar's economy. This result is consistent with oil-exporting countries.

Table 5. Granger Causality Results

\begin{tabular}{llll}
\hline Null Hypothesis $\left(\mathrm{H}_{0}\right)$ & Wald Test $/ \chi^{2}$ & Prob. & Conclusion \\
\hline $\begin{array}{l}\text { LRGEXP does not Granger } \\
\text { Cause LRGREV }\end{array}$ & 1.7073 & 0.1913 & can't reject $\mathrm{H}_{0}$ \\
\hline $\begin{array}{l}\text { LRGREV does not Granger } \\
\text { Cause LRGEXP }\end{array}$ & 8.1168 & 0.0044 & reject $\mathrm{H}_{0}$ \\
\hline
\end{tabular}

LRGREV is log of real government revenue; LRGEXP is log of real government expenditure.

\section{Conclusion}

This research has attempted at providing evidence on the relationship between government revenue and expenditure in Qatar for the period from 1980-2011. Both unit root tests ADF and Phillip-Perron found the variables to be integrated of order one. Engle-Granger's approach of cointegration found government revenue and expenditure to be cointgrated, and hence, a long-run relationship between them exists. Granger causality test found unidirectional causality running from government revenue to government expenditure. This supports revenue-spend hypothesis. The result is different than that of Fasano and Wang (2002) findings on Qatar, but similar to the causality results for Bahrain, The United Arab Emirates and Oman in the same study.

\section{References}

Aisha, Z., \& Khatoon, S. (2009). Government Expenditure and Tax Revenue Causality and Cointegration: The Experience of Pakistan 1972-2007. The Pakistan Development Review, 48(4), 951-959.

Al-Qudair, K. H. (2005). The Relationship between Government Expenditure and Revenue in the Kingdom of Saudi Arabia: Testing for Cointegration and Causality. Journal of King Abdulaziz University, 19(1), 31-43.

Amoah, B., \& Loloh, F. W. (2008). Causal Linkages between Government Revenue and Spending: Evidence from Ghana. Working Paper, WP/BOG-2008/08. Bank of Ghana.

Batainah, K. I. (Undated). Government Revenues and Expenditures: Causality Tests for Jordan. www.mop.gov.jo/upload/Government\%20Revenues\%20Expenditures\%20Jordan.pdf.

Causality and Cointegration: The Experience of Pakistan 1972-2007. The Pakistan Development Review, 48(4), 951-959.

Eita, J. H., \& Mbazima, D. (2008). The Causal Relationship between Government Revenue and Expenditure in Namibia. http://mpra.ub.uni-munchen.de/9154/MPRA Paper No. 9154, posted 16. June, 16:04

Elyasi, Y., \& Rahimi, M. (2012). The Causality between Government Revenue and Government Expenditure in Iran. International Journal of Economic Sciences and Applied Research, 5(1), 129-145.

Engle, R. F., \& Granger, C. W. J. (1987). Cointegration and error correction: Representation, estimation, and testing. Econometrica, 2, 251-276.

Fasano, U., \& Wang, Q. (2002). Testing the Relationship between Government Spending and Revenue: evidence from GCC Countries. IMF Working Paper, WP/02/201, International Monetary Fund.

Granger, C. W. J. (1969). Investigating the Causal Relations by Econometrics Models and Cross-Spectral Methods. Econometrica, 37(3), 424-438.

Gujarati, D. N., \& Porter, D. C. (2009). Basic Econometrics. McGraw-Hill International Edition.

Harris, R. I. (1995). Using Cointegration Analysis in Econometric Modeling. Pearson Education.

Masenyetse, R. F., \& Motelle, S. I. (2012). Government Revenue - Expenditure Nexus in Lesotho: the Decline in SACU Revenue. American Journal of Economics, 2(1), 8-14.

Ministry of Economics and Commerce. (1990). Economic Development (1980-1989). New Printing Company. 
Nyamongo, M. E., Sichei, M. M., \& Schoeman, N. J. (2007). Government Revenue and Expenditure Nexus in South Africa. SAJEMS NS 10(2), 256-268.

Petanlar, S. K., \& Sadeghi, S. (2012). Relationship between Government Spending and Revenue: Evidence from Oil Exporting Countries. International Journal of Economics and Management Engineering, 2(2), 95-97.

Pndyck, R., \& Rubinfeld, D. (1998). Econometric Models and Economic Forecasts, $4^{\text {th }}$ Ed. McGraw-Hill.

Qatar Central Bank. Annual Report. Various issues.

Qatar Statistics Authority. www.qsa.org.qa

Ravinthirakumaran, K. (2011). The Relationship between Government Revenue and Expenditure in Sri Lanka. Proceedings of Second International Research Conference on Business and Information. Faculty of Commerce and Management Studies, University of Kelaniya, Sri Lanka.

Revenue and Expenditure in Namibia. (2008). http://mpra.ub.uni-munchen.de/9154/MPRA Paper No. 9154, posted 16. June 2008/ 16:04.

Sadiq, T. (2010). The Causality between Revenues and Expenditure of the Federal and Provincial Governments of Pakistan. The Pakistan Development Review, 49(4), 651-662.

Subhani, M. I., Hasan, S. A., Osman, A., \& Rafiq, T. (2012). An Investigation of Granger Causality between Tax Revenues and Government Expenditures. European Journal of Scientifics Research, 68(3), 340-344.

Tsen, W. H., \& Kian-Ping, L. (2005). The Relationship between Government Revenue and Expenditure in Malaysia. International Journal of Management Studies, 12(2), 53-72. 